$\begin{array}{lll}\text { KULTURA } & \begin{array}{l}\text { POLSKA A KADEMIANAUK } \\ \text { KOMITET SOCJOLOGII }\end{array} & \text { ISSN 0023-5172 } \\ \text { i } & \begin{array}{l}\text { INSTYTUT STUDIÓW POLITYCZNYCH } \\ \text { SPOLECENSTWO }\end{array} & \\ \text { 2018, nr } 2 & \text { PRZEMIANY WIĘZI }\end{array}$

JAN LUTYNSKI

\title{
DZIAŁANIA POZORNE
}

Zgodnie $z$ określeniami w słownikach, działaniami pozornymi należałoby nazwać takie czynności, które ze względu na swoje najważniejsze cechy są inne, niż na to wyglądają. Ponieważ przez „działanie” rozumie się zawsze czynność celową, zaś bezpośredni cel działania zalicza się do cech ważnych, odmienności działań pozornych od innych można upatrywać również w tym, że nie realizują one swoich bezpośrednich celów, które powinny realizować zgodnie z wyobrażeniami rozpowszechnionymi w danym społeczeństwie i kulturze. Pozorne są więc takie działania, które - ze względu na swój rzeczywisty przebieg lub bezpośredni cel — są inne, niż na to wyglądają.

Do tak szeroko rozumianych działań pozornych można włączyć bardzo różne czynności. Należą do nich, między innymi: przynajmniej niektóre działania naśladowcze; wszystkie działania wykonywane „na pokaz”; działania ceremonialne przynajmniej ze względu na swój bezpośredni sens; czynności służące za pretekst dla działań innych; niektóre działania asekuracyjne i prowokacyjne, a nawet działania po prostu nieudolne, jeśli zewnętrzny ich wygląd lub wygląd ich rezultatu nie odbiega od przyjętego wzoru. Zaliczyć trzeba do tych działań również wszelkie czynności, które bezpośrednio lub ze względu na wynik nie spełniają swoich założonych funkcji, przy czym dzieje się tak zgodnie z zamierzeniami wykonawców czy zleceniodawców, a wbrew interesom i bez wiedzy tych, dla których są wykonywane. Takimi oszukańczymi działaniami będą na przykład: zła naprawa obuwia, przygotowanie sprawozdania $z$ działalności, w którym oszukuje się zwierzchników, czy posługiwanie się nie zmienioną nazwą produktu, sprzedawanego po tej samej cenie, chociaż obniżyła się jego jakość. Wykonuje się je z myślą o tym, aby osiągnąć jak największe korzyści przy jak najmniejszym nakładzie kosztów. Działania oszukańcze podejmowane 
są bądź w stosunku do zwykłych, równych wykonawcy odbiorców danej usługi czy produktu, bądź też są one kierowane „w górę” lub „w dół”.

Wymienić trzeba w końcu jeszcze jeden rodzaj działań, na pewno zresztą nie ostatni ${ }^{1}$, które przy szerokim rozumieniu zasługują na nazwę pozornych. Pod pewnymi względami zbliżone one są do poprzednich, a także do tych czynności, którym w dalszym ciągu artykułu poświęcę więcej uwagi. Są to działania wykonywane tylko formalnie, „na papierze”, działania szczątkowe, za które jednak otrzymuje się nieraz wysoki materialny ekwiwalent. Jest to jednak zarazem ekwiwalent za inne działania, które nie mogą być wynagradzane materialnie. Przykładem może być tutaj fikcyjna działalność zawodowa wybitnego sportowca czy działacza, formalnie tylko pracownika danego zakładu pracy.

Niektóre z wymienionych rodzajów działań mieli na myśli autorzy artykułów i listów opublikowanych niedawno w „Polityce” na temat działań pozornych $^{2}$. Powoływali się oni jednak również na przykłady należące do innej kategorii. Tą kategorią działań - zresztą zróżnicowanych i w praktyce nie zawsze łatwych do wyodrębnienia od innych, zwłaszcza od działań oszukańczych — zajmę się bliżej w tym artykule. Dla ułatwienia będę je nazywać po prostu działaniami pozornymi, co nie oznacza, że nazwa ta nie powinna przysługiwać również innym czynnościom. Należy jednak pamiętać, że obejmowanie jedną nazwą zjawisk zbyt różnorodnych rozszerza jedynie jej zakres, a nie wzbogaca treści, która może być zbyt uboga, aby dane pojęcie było całkowicie użyteczne.

Działania pozorne, które mam tu na myśli, odznaczają się następującymi cechami: po pierwsze - oficjalnie uznaje się je za istotne dla realizacji, niekoniecznie samodzielnej, jakiegoś ważnego społecznie celu; po drugie - celu tego faktycznie nie realizują, względnie nie przyczyniają się do jego realizacji, podobnie zresztą jak i wszystkie poprzednio wymienione rodzaje działań; po trzecie - w przeciwstawieniu do większości działań poprzednich - o nieprzydatności tego rodzaju działań wiedzą wszyscy lub prawie wszyscy w danej zbiorowości czy społecznym systemie; po czwarte — jest to wiedza prywatna, nie jest ona publicznie, zwłaszcza oficjalnie uzewnętrzniana; po piąte - wystarczającą, choć nie zawsze jedyną, racją ich występowania w jakiejkolwiek postaci jest to, że przypisano im istotną rolę $\mathrm{w}$ realizacji danego celu; ich rzeczywista funkcja polega więc zawsze - co nie znaczy wyłącznie - na ich istnieniu, przy czym może być to również istnienie w postaci szczątkowej, jedynie formalne.

Jak widać, omawiane działania odznaczają się — zawsze łącznie — kilkoma cechami, które w pełnym zestawie nie charakteryzują innych działań, określa-

\footnotetext{
${ }^{1}$ Interesujący rodzaj działań pozornych — przy bardzo szerokim ich rozumieniu — stanowi artykulacja dążeń społecznych jakiejś grupy przy użyciu języka odległego od sfery tych dążeń, lecz rozpowszechnionego $\mathrm{w}$ danej epoce, na przykład języka religijnej ideologii. Licznych przykładów $z$ tego zakresu dostarczają dzieje ruchów społecznych. Przykłady innych jeszcze działań pozornych w szerokim sensie wymieniam w przypisie 3 .

2 M. Radgowski, Działalność pozorna, „Polityka” 1976, nr 48; J. Głażewski, Mitologia działalności pozornej, czyli nie deptać trawników, „Polityka” 1977, nr 2; Listy czytelników, „Polityka” 1977, nr 3 i 12.
} 
nych poprzednio także jako pozorne. Do tych pięciu cech należy dodać jeszcze jedną, szóstą z kolei: wszystkie działania, którym z pewnym uzasadnieniem można przypisać cechę pozorności, zawierają jakiś element fikcji, odnoszący się do ich przebiegu czy celu. W przypadku naszych działań ich fikcyjność przynajmniej ze względu na założony cel — jest wszystkim znana. Mimo to istnieją, utrzymują się. Wymaga to jednak zawsze pewnego rodzaju nacisku, przymusu, choćby był to tylko nacisk autorytetu, usprawiedliwiający zbiorowe przemilczanie, obłudę lub zakłamanie. Ten nacisk nie występuje w przypadku działań poprzednio wymienionych, w których element fikcji jest ukryty lub zrekompensowany w inny sposób ${ }^{3}$.

Przejdźmy jednak do omówienia przykładów działań pozornych w scharakteryzowanym tu sensie, które skonkretyzują dotychczasowe abstrakcyjne $z$ konieczności rozważania. Przykłady zaczerpnięto z bliskiej nam, a więc i najlepiej znanej rzeczywistości, co nie znaczy, że interesujące nas zjawiska występują tylko w jednym czy w niewielu krajach i w jednej epoce. Przeciwnie, zakres ich występowania nie jest czasowo i przestrzennie ograniczony. Jednak ich nasilenie zależy od epoki i kraju, warto się więc nimi zająć. Przytoczone przykłady wskazują jednocześnie na określone mechanizmy wywołujące działania pozorne, na ich źródła w społecznej rzeczywistości. Mechanizmy te są różne, gdyż i działania pozorne w przyjętym tu znaczeniu są zróżnicowane. Wykaże to dalsza analiza, w której jednak łatwo będzie wskazać również i na dalsze ich wspólne cechy i konsekwencje.

Jako pierwszy trzeba wymienić mechanizm tkwiący w strukturze organizacyjnej, instytucjonalnej i, jednocześnie, w systemie podejmowania decyzji, a więc - mechanizm organizacyjno-decyzyjny. Przypuśćmy, że podjęcie jakiejś konkretnej decyzji, na przykład personalnej, należy statutowo do instytucji danego szczebla w hierarchii organizacyjnej. Przypuśćmy również, że ta decyzja została podjęta $\mathrm{w}$ instytucji wyższego szczebla, od której dana insty-

${ }^{3} \mathrm{~W}$ krańcowych przypadkach rekompensatę stanowić może nawet przeświadczenie, że dane działania wzmacniają morale grupy. Sytuacja taka występuje wówczas, gdy w obliczu groźnego niebezpieczeństwa $\mathrm{w}$ danej grupie podejmuje się działania, które faktycznie nie mogą odsunąć niebezpieczeństwa, choć rzekomo dlatego właśnie są wykonywane. O ich pozornym charakterze wiedzą członkowie tej grupy, lecz nie ujawniają tego, ponieważ zdają sobie sprawę, że jakakolwiek organizowana aktywność ma pozytywne znaczenie dla grupy, zapobiega panice, przywraca wiarę we własne siły itp., co może mieć znaczenie dla ocalenia od klęski. Pewnego rodzaju zakłamanie, które także towarzyszy tym działaniom, zrekompensowane jest więc nie na drodze przymusu. Działania tego rodzaju, znane dobrze, między innymi z pamiętników z ostatniej wojny, ze względu na wszystkie wymienione $\mathrm{w}$ tekście cechy, poza przymusem, zbliżone są do czynności będących przedmiotem tego opracowania. Ze względu na inne cechy podobne są do nich również pewne działania pozorne (w szerokim sensie), wykonywane właśnie w warunkach skrajnego, fizycznego przymusu. Mam tu na myśli wyczerpujące fizycznie i zarazem bezsensowne prace, do których zmuszano więźniów w hitlerowskich obozach, w obozie odosobnienia w Berezie Kartuskiej, a zapewne i w innych, przy czym bezsensowność pracy była dodatkową karą. Działania te odróżnia od czynności pozornych, interesujących nas głównie w tym szkicu, brak pierwszych trzech cech, uznanych w tekście za charakterystyczne dla działań pozornych. 
tucja, jej kierownictwo i pracownicy są zależni. Działanie decyzyjne w instytucji niższej potwierdzi wówczas zawsze decyzję instytucji wyższego szczebla, choćby ze względu na jej autorytet. Bardziej konkretny przykład stanowi tutaj wybór na jakieś stanowisko kandydata „przywiezionego w teczce”, niezależnie od tego, czy jest to wybór dokonany przez wszystkich członków jakiejś organizacji, przez ciało przedstawicielskie jakiegokolwiek szczebla, czy też decyzję nominacyjną podjął kierownik, naczelnik czy dyrektor. Działania takie mają charakter pozorny w przyjętym sensie, gdyż nie realizują one faktycznie swego celu, który w tym przypadku został już zrealizowany, jednocześnie zaś wiedzą o tym wszyscy zaangażowani w proces decyzyjny, najczęściej — również i obserwatorzy.

Mechanizm organizacyjno-decyzyjny był już omawiany w literaturze, podobnie zresztą jak niektóre pozostałe ${ }^{4}$. Występuje on także w odmiennych sytuacjach, na przykład gdy wiążące decyzje podejmowane są w innym pionie organizacyjnym niż pion administracyjny czy związkowy, do którego statutowo należą. Może być zresztą i tak, że te wiążące decyzje zapadają w jednostce formalnie organizacyjnie niższej, co zdarza się jednak rzadko, względnie podejmuje je nieformalna grupa lub osoba reprezentująca trwale rzeczywistą władzę czy autorytet w danym systemie, co występowało często w okresie „kultu jednostki" w różnych krajach i na różnych stanowiskach ${ }^{5}$. Rezultatem postanowień podjętych $\mathrm{w}$ ten sposób są zawsze działania pozorne odnoszące się do sfery decyzji, oczywiście nie tylko personalnych, jak w podanym tu przykładzie.

Odrębny od poprzedniego mechanizm, wywołujący działania pozorne, dotyczy sfery wartości i dlatego nazwijmy go a ksjologicznym. W każdej kulturze i systemie występują wartości, które są uznawane, ale nie są realizowane, przynajmniej aktualnie, $\mathrm{w}$ niektórych czy $\mathrm{w}$ wielu przypadkach. Jeśli $\mathrm{w}$ danym systemie silna jest chęć wykazania, że te wartości są w całości akceptowane i realizowane, mogą być podjęte działania, o których głosi się, że je realizują. Taką funkcję przypisuje się im dlatego, że pełnią ją rzeczywiście w innych sytuacjach. W danej sytuacji faktycznie nie służą temu celowi, co jest publiczną tajemnicą. Są więc pozorne, występują zaś ze względu na przypisywany im cel.

Za przykład takich działań mogą służyć badania naukowe podjęte w jakimś przedsiębiorstwie w specyficznych warunkach. Przeprowadzenie ich zostało zlecone przy założeniu (założony cel), że wyniki będą wykorzystywane przy podejmowaniu decyzji. Kierownictwu tego przedsiębiorstwa faktycznie nie zależy jednak na tym, aby ów cel realizować, gdyż rodzaj decyzji określiły już inne czynniki, o czym wiedzą wszyscy zainteresowani. Jednocześnie jednak kierownictwu zależy na tym, aby wykazać, że jego postanowienia oparte są na naukowych podstawach, że ceni ono wysoko naukę ze względu na jej praktyczne zastosowania. Dlatego właśnie zaleca przeprowadzenie badań. Oczywiście,

${ }^{4}$ Por. J. Staniszkis, Patologia organizacji, Warszawa 1972, oraz tejże autorki Odmiany władzy (z problemów sterowania $w$ wielkich systemach), „Studia Socjologiczne” 1973, nr 2.

${ }^{5}$ Por. wystąpienie Władysława Gomułki, „Nowe Drogi” 1956, nr 10, zwł. s. 39-41. 
w tych warunkach należą one do działań pozornych, przynajmniej ze względu na ich funkcje praktyczno-użytkowe.

Działania składające się na twórczość naukową bywają pozorne również z innych względów. Są nimi zawsze, gdy twórczość naukowa nie przyczynia się - jako twórczość jednego człowieka lub w całej dziedzinie wiedzy — do realizacji wartości poznawczych, choćby była oficjalnie uznana za taką i odwoływała się do tych wartości, spełniając inne funkcje, na przykład perswazyjne. O sytuacjach tego rodzaju wiedzą z reguły wszyscy zainteresowani, a zwłaszcza środowisko pracowników nauki.

Mechanizm aksjologiczny wywołuje jednak działania pozorne w przyjętym tu znaczeniu nie tylko w sferze nauki. Do takich działań należą również na przykład wypowiedzi w zorganizowanej dyskusji czy serii wystąpień, których treść jest $z$ góry zaplanowana i dostosowana do wyniku obrad lub danej akcji, lecz którym przypisuje się obcy im charakter spontaniczności; następnie - niektóre aklamacyjne głosowania itp. Takie działania pozorne mają często charakter zinstytucjonalizowany, podejmowane są również $\mathrm{w}$ ramach organizacji, których aktywność niekiedy do nich się głównie sprowadza. Wartości, o których akceptacji świadczyć mają omawiane działania, pochodzą zazwyczaj z innych społecznych systemów lub z wcześniejszych okresów historycznych. Mogą jednak pojawić się i w tym samym społecznym systemie; wówczas są to $z$ reguły takie nowo wprowadzone wartości, które - wbrew założeniom lub oczekiwaniom - nie uzyskały rzeczywistej akceptacji ze strony ogółu. Aby potwierdzić tę akceptację, podejmuje się odpowiednie działania, a nawet tworzy się organizacje o częściowo przynajmniej pozornym charakterze. Przykładem są organizacje kulturalne, a nawet samorządowe wprowadzone z góry, kiedy brak jest trwałego zainteresowania nimi ze strony tych, którym mają służyć. Ich działalność zatem musi mieć charakter pozorny, gdyż nie są one w stanie realizować odpowiednich wartości, co miało być właśnie zadaniem tych organizacji.

Następny mechanizm wywołujący działania pozorne - to mechanizm związany $z$ występowaniem nieżyciowych przepisów i poleceń. Można go nazwać mechanizmem obowiązkowego wykonawstwa nieżyciowych rozporządzeń. Źródłem wywoływanych przez ten mechanizm działań pozornych jest obowiązek wykonywania tego, co w ogóle względnie w przewidziany sposób wykonać się nie da lub co dla osiągnięcia danego celu jest faktycznie niepotrzebne. Niemożliwość realizacji tych działań wynika z różnych powodów: $z$ fałszywych założeń dotyczących rzeczywistości, przyjętych w rozporządzeniu $^{6} ; \mathrm{z}$ faktu, że czynności $\mathrm{w}$ nich przewidziane wymagają czasu, którego

\footnotetext{
${ }^{6}$ Przyjmowanie w przepisach i wszelkich rozporządzeniach fałszywych założeń, odnoszących się do rzeczywistości, może być po prostu rezultatem braku wiedzy. Może także pozostawać W związku z ogólnym nastawieniem wobec rzeczywistości, którą widzi się przez pryzmat fikcji. W takich przypadkach również tworzenie przepisów można uznać za działalność pozorną (przynajmniej w szerokim znaczeniu), ponieważ nie mogą one spełnić swej funkcji.
} 
po prostu nie ma; $z$ tego, że wykonanie ich powoduje nadmierne zaabsorbowanie jakiegoś grona ludzi, którzy muszą wykonywać inne zasadnicze dla nich czynności itp.

Działania przewidziane przez takie nieżyciowe rozporządzenia nie są z reguły w całości wykonywane. Zwykle są to działania czysto formalne, o charakterze szczątkowym. Sprowadzają się one wówczas do stwierdzenia, najczęściej na piśmie, że wystąpiło coś, co faktycznie nie wystąpiło, na przykład, że wykonana została rzekomo kontrola, która przyniosła określone rezultaty, że uczniowie poświęcili odpowiednio dużą liczbę godzin na prace społeczne, podczas gdy faktycznie liczba ta była mniejsza. Oczywiście, takie szczątkowe działania nie przyczyniają się do realizacji celu, który powinny realizować. W tym zakresie, $\mathrm{w}$ jakim nas one tutaj interesują, ich pozorny charakter nie jest tajemnicą dla zleceniodawców tych działań ani dla bezpośrednio zainteresowanych.

Nie zawsze szczątkowy charakter mają natomiast działania pozorne niepotrzebne dla realizacji jakiegoś celu, który jest lub może być zrealizowany w wyniku innych działań. Nieżyciowe - a więc w tym przypadku niepraktyczne rozporządzenie, najczęściej przepis, wymaga jednak podjęcia dodatkowych zadań, na przykład: osobistego stawiennictwa, podczas gdy wystarczy pismo lub telefon; dodatkowych informacji, opinii czy sprawozdań, podczas gdy wystarczą już otrzymane „podkładki”, względnie dużo mniejsza ich liczba. Niepotrzebne działania pozorne nie zawsze mają charakter czynności biurokratycznych, jak w podanych przykładach. Należy do nich bowiem także produkcja nikomu niepotrzebnych wyrobów, produkcja tylko „na magazyn”, tylko po to, aby wykonać rozporządzenie zawarte $\mathrm{w}$ planie. Oczywiście i w tych przypadkach zbędność działań znana jest wszystkim zaangażowanym, nie wyłączając zleceniodawców. Gdyby było inaczej, byłyby to działania oszukańcze, które również są częstą reakcją na nieżyciowe rozporządzenia wszelkiego rodzaju, zarówno niemożliwe do zrealizowania, jak i prowadzące do działań niepotrzebnych.

Ostatni z wyróżnionych mechanizmów należy także do sfery wydawania i wykonywania poleceń. Można go nazwać mechanizmem rzekomo prag mat y c z ny m. Występuje on zwłaszcza w sytuacjach, kiedy czynniki decydujące nie mogą lub nie chcą rozwiązać jakiegoś problemu traktowanego jako ważny przez obywateli. Dzieje się tak zwykle dlatego, że rozwiązanie to prowadziłoby do niepożądanych dla nich następstw lub też wymagałoby zastosowania określonych środków, co jest bądź niemożliwe, bądź też zostało uznane za niecelowe. Pragnąc jednak wykazać, że problem ten jest rozwiązywany lub, co najmniej, że rozwiązanie to uważa się a ważne, zleca się podjęcie działań lub podejmuje się czynności, które faktycznie do tego nie prowadzą, lecz które oficjalnie zostały uznane za działania właściwe i potrzebne. Ci, którzy te działania wykonują, na przykład uczestnicy narad, zebrań czy konferencji, zwołanych zamiast zastosowania niezbędnych środków, zdają sobie na ogół sprawę z ich pozornego charakteru, podobnie zresztą jak zleceniodawcy i obserwatorzy. Do działań pozornych wywołanych przez ten mechanizm należą również niektó- 
re reorganizacje, kontrole, niekiedy i kary nakładane na wykonawców innych działań, nieudanych nie $z$ ich powodu, następnie - pewne akcje propagandowe, o których z góry wiadomo, że nikogo nie przekonują, oraz wiele innych. Czasami mechanizm rzekomo pragmatyczny prowadzi nawet do pojawienia się instytucji czy organizacji o częściowo przynajmniej pozornym charakterze.

Dokładniejsza analiza, zwłaszcza uwzględniająca szerszy zakres zjawisk, wskazałaby zapewne i na inne jeszcze mechanizmy powodujące pojawienie się działań pozornych, rozumianych zgodnie z podanym ich określeniem. Sądzę jednak, że scharakteryzowane tu mechanizmy wywołują ich znaczną większość. Zgodnie z tym, o czym była już mowa, działania te są zróżnicowane. Najważniejsze różnice dotyczą realizacji celu oraz sprawy przebiegu tych działań, a także kwestii ich rzeczywistych funkcji nie związanych z tym celem.

Jak wynika z określenia działań pozornych, nie przyczyniają się one faktycznie do realizacji przypisywanego im celu. W niektórych przypadkach jednak cel ten, na przykład podjęcie decyzji o wyborze kogoś na dane stanowisko, może być zrealizowany przez inne działania, zresztą inaczej, w inny sposób. Natomiast $\mathrm{w}$ sytuacjach innych cel ten nie jest w ogóle realizowany, niekiedy zgodnie z zamierzeniami decydentów, jak to występuje w przypadku niektórych działań wywołanych przez mechanizm rzekomo pragmatyczny.

Częściowo fikcyjny, nawet szczątkowy charakter mogą mieć również same działania. Dzieje się tak zawsze, gdy są one niemożliwe do zrealizowania w pełnym zakresie. Niekiedy może być tak i w innych sytuacjach, na przykład gdy są one po prostu niepotrzebne. Ale ta ostatnia okoliczność, podobnie zresztą jak inne, nie pociąga za sobą fikcyjności działań co najmniej w dwóch przypadkach: gdy dane działanie ma realizować także inne, realne cele lub gdy wykonywane jest ono publicznie. W tym drugim przypadku zewnętrzny przebieg działań jest $z$ reguły zgodny $z$ ich wzorem. Są one bowiem wówczas również typowymi działaniami „na pokaz”, działaniami „fasadowymi”.

Wspomniane tu inne cele działań pozornych mogą być rzeczywistymi celami ich wykonawców czy zleceniodawców i nie muszą być publicznie ujawniane. Wiąże się z tym fakt, że działania pozorne $\mathrm{w}$ przyjętym tu znaczeniu spełniają bardzo często jeszcze inne funkcje poza funkcją szczątkowego choćby występowania. Bywa to na przykład funkcja sprawdzenia lojalności czy umiejętności wykonywania polecenia oraz wiele innych, w tym także zgodnych $z$ interesem wykonawców. Tak więc zabranie głosu w zaplanowanej z góry „spontanicznej” dyskusji dostarcza pożądanego rozgłosu, jednocześnie zaś często jest uważane za wyróżnienie. Produkcja „bubli” dla wykonania planu pozwala wypłacić premie pracownikom itd.

Wspomniane inne funkcje działań pozornych są bardzo różnorodne. Tak więc akcja propagandowa, o której się wie, że nie ma na celu przekonania odbiorców, faktycznie może wskazywać język, którym należy się posługiwać, gdy publicznie porusza się daną kwestię. Wiele akcji pozornych wywoływanych przez różne mechanizmy wykonuje się w sposób polegający na utrzymaniu 
w sprawności aparatu wykonawczego, względnie - dostarczający uzasadnienia, a raczej wytłumaczenia słuszności jego istnienia czy rozbudowy. (Oczywiście pozorny - $\mathrm{w}$ przyjętym tu sensie - charakter tych akcji nie oznacza, że nie mają one dużego znaczenia, na przykład dla ich uczestników czy odbiorców). Wciągając ludzi do różnych pozornych akcji w imię wartości, których oni nie uznają, można stopniowo przekonywać ich do nich, korzystając z mechanizmów dobrze znanych psychologii. Niemała część działań pozornych umożliwia ich inicjatorom „zachowanie twarzy” w danej zbiorowości lub na zewnątrz niej, sprzyja przetrwaniu w ludzkiej świadomości bądź wprowadzeniu do niej obrazu świata, w którym wizerunek ich samych namalowany jest ciepłymi barwami. Ma to niewątpliwie znaczenie i dla podtrzymania ich dobrego mniemania o sobie, co jest przecież powszechną ludzką potrzebą. Te inne funkcje działań pozornych w wielu przypadkach są zapewne główną racją ich istnienia.

Działania pozorne różnią się między sobą jeszcze pod innymi względami. Różny zakres i charakter może mieć związany z nimi nacisk, a co za tym idzie - również stopień prywatności opinii o ich pozornym charakterze. Niektóre mają charakter sporadyczny, inne występują stale jako ważna część aktywności danej instytucji czy organizacji, decydując niekiedy o jej istnieniu. Biorąc pod uwagę to, czy obok pozornego mają one jeszcze jakieś inne, realne cele lub frakcje uboczne, następnie - to, czy ich pozorny cel jest realizowany, a także — to, czy same mają charakter szczątkowy, można mówić o stopniu, w jakim są one pozorne. Najwyższy stopień osiągnęłyby działania podejmowane w celu, który faktycznie nie jest realizowany, nie pełniące żadnej innej roli poza tym, $\dot{z}$ e istnieją w szczątkowej formie. Stopień najniższy przypadłby działaniom rzeczywiście wykonywanym, których cel został zrealizowany przez działania inne i które dodatkowo pełnią wiele istotnych, ważnych społecznie funkcji. Stopnie te układają się, oczywiście, w skalę, którą jednak zapewne trudno byłoby uczynić skalą w całości poprawną metodologicznie ze względu na niemierzalny lub co najmniej trudno mierzalny - charakter zjawisk.

Niezależnie od wszystkich różnic trzeba jednak podkreślić, że - nawet nie biorąc pod uwagę konsekwencji, o których piszę dalej — wszystkie działania pozorne w przyjętym tu znaczeniu mają wspomniane poprzednio istotne cechy wspólne. Należy do nich zwłaszcza fakt, że u ich podłoża leży zawsze jakaś niespójność, brak zgodności, przede wszystkim brak zgodności między tym, co się głosi lub zakłada, a tym, co rzeczywiście się realizuje. $Z$ tym brakiem zgodności związany jest ściśle element fikcji i zakłamania. Jego rola w życiu społecznym — jak wiadomo - bywa różna. W szerszym zakresie element ten może jednak występować tylko wówczas, gdy ranga wartości poznawczych w porównaniu $z$ innymi wartościami $w$ danym społeczeństwie nie jest zbyt wysoka.

Uwypuklając wspólne cechy wszystkich działań pozornych, o których tu mowa, należy jeszcze wspomnieć o jednej łączącej je sprawie. Chociaż mechanizmy, które je wywołują, a także ich odmiany, różnią się od siebie, to jednak często uzupełniają się i wspólnie sprawiają, że występuje dane działanie po- 
zorne. Przykład stanowić może samorząd pracowniczy, oczywiście w tych przypadkach i zakresie, kiedy jego działalność ma charakter pozorny w przyjętym tu znaczeniu. Szukając mechanizmów, które go wywołują, należałoby wskazać wszystkie dotychczas wymienione, a zapewne i inne. Kilka mechanizmów łącznie wywołać może również pewne z poprzednio wymienionych działań, które kolejno wiązaliśmy w zasadzie $z$ jednym $z$ tych mechanizmów.

Dlaczego ludzie podejmują działania pozorne lub w nich uczestniczą? Postawienie tego pytania jest celowe choćby dlatego, że same przez się nie są one atrakcyjne, przynajmniej dla dużej części wykonawców. Nie są atrakcyjne ze względu na swoją nieautentyczność, którą powoduje wspomniany brak zgodności. Są nieatrakcyjne również ze względu na to, że często towarzyszy im świadomość przymusu, a w przypadku wielu działań przekonanie, że są bezużyteczne lub nawet szkodliwe. Jednak ludzie wykonują działania pozorne, uczestniczą w nich, niekiedy dość często. Robią to jednak głównie nie dla nich samych, lecz ze względu na ich uboczne i rzeczywiste funkcje, które w danej sytuacji pozwalają im osiągnąć to, co uważają za korzystne, a uniknąć tego, co niekorzystne, a niekiedy i tego, co zgubne. Korzyść należy przy tym pojmować tu nie tylko jako korzyść osobistą. Bywa to także korzyść ponadjednostkowa, którą wykonawca może uznać za większą od niedogodności czy szkód wyrządzanych przez dane działanie pozorne. Czasami zresztą uczestnictwo w działaniach pozornych jest ceną świadomie akceptowaną za podjęcie działań własnych, dla których bodźcem jest nie tylko ambicja, lecz również autentyczna potrzeba realizacji społecznie ważnych celów.

Takie pragmatyczne i racjonalistyczne stanowisko w stosunku do działań pozornych, o ile nie sprowadza się do racjonalizacji, może neutralizować ich skutki. Są one wielostronne, przy czym o niektórych z nich była już mowa $\mathrm{w}$ związku $\mathrm{z}$ ich funkcjami. Zatrzymam się obecnie na skutkach $z$ pewnego punktu widzenia najważniejszych.

Przede wszystkim trzeba stwierdzić, że działania pozorne przyczyniają się do obniżenia morale obywatelskiego i pracowniczego ich wykonawców, obserwatorów, a nawet zleceniodawców. Rozpowszechnienie działań pozornych podważa wiarę w autentyczność nie tylko związanych z nimi, lecz i innych akceptowanych publicznie wartości i celów społecznego działania, usprawiedliwia obojętność i brak wewnętrznego zaangażowania w stosunku do nich. Uczestnictwo w licznych działaniach pozornych, które w części nie są wykonywane, lub mogą być wykonywane niedbale, przyczynia się do rozpowszechnienia wzorów „złej roboty”. Uczestnictwo to usprawiedliwia także działania oszukańcze podejmowane $\mathrm{w}$ interesie własnym na szkodę zbiorowości. Jeśli bowiem ktoś nakłaniany jest do wykonywania nieatrakcyjnych czynności, w których obecny jest element fikcji, to dlaczego nie ma on podjąć sam innych działań, w których także występują elementy fikcji, ale które przynajmniej przynoszą mu wyraźne korzyści? Dlaczego tego nie zrobić właśnie wówczas, gdy w błąd wprowadza się tych, którzy sami aprobują fikcję? Oczywiście, takie usprawiedliwienie bynaj- 
mniej nie jest potrzebne, aby podjąć działania oszukańcze, na przykład w pracy zawodowej, co jest nieraz reakcją na skierowane „W dół” działania tego samego rodzaju lub - najczęściej - pojawiają się one samorzutnie. Usprawiedliwienie takie może jednak odgrywać pewną rolę w ich upowszechnianiu. Warto natomiast pamiętać, że upowszechnienie działań oszukańczych pociąga za sobą rozległe społeczne i ekonomiczne skutki. Wystarczy wspomnieć tylko o jednej wąskiej dziedzinie - o sprawozdawczości, w której podaje się fałszywe dane, i o konsekwencjach tego dla trafności podejmowanych ważnych nieraz decyzji ${ }^{7}$.

Osłabienie morale obywatelskiego i pracowniczego przyczynia się także znowu zresztą tylko w pewnym zakresie - do formalizacji działalności w życiu kulturalnym i zawodowym. Jeden $z$ ważnych, wskazanych już, aspektów tego osłabienia stanowi odrzucenie identyfikacji z ogólnymi celami działalności $\mathrm{w}$ tym życiu. Prowadzi to niejednokrotnie do postępowania niezgodnego $\mathrm{z}$ tymi celami. Aby temu przeciwdziałać, mnoży się przepisy zabraniające jednych zachowań i nakazujące postępowanie w określony sposób, zaś fakt, że przepisy bywają nieżyciowe, sprzyja pojawieniu się działań pozornych wraz z ich skutkami. W ten sposób obniżenie morale obywatelskiego i pracowniczego oraz formalizacja życia w omawianych sferach wpływają na siebie wzajemnie, o czym wspomina się także w powoływanej tu literaturze. Występują między nimi wzmacniające sprzężenia zwrotne również za pośrednictwem działań pozornych, które uczestniczą w tym sprzężeniu.

Działania pozorne wywołują także bezpośrednio określone ekonomiczne oraz organizacyjne skutki i to nie tylko wtedy, gdy są nimi niepotrzebne działania produkcyjne. Wiele działań pozornych wymaga zaangażowania niemałych środków. Poza tym zabierają one bezproduktywnie czas. Trzeba zaś zauważyć, że wiele $\mathrm{z}$ nich obciąża kadrę kierowniczą i administracyjną nieraz $\mathrm{w}$ dużym stopniu, zmniejszając wydatnie efektywność jej postępowania.

Społeczne skutki działań pozornych łatwo jest uznać za negatywne. Dotyczy to zarówno ich skutków bezpośrednich, zwłaszcza ekonomicznych i organizacyjnych, jak i pośrednich, zwłaszcza w sferze postaw, które z kolei pociągają za sobą dalsze niekorzystne następstwa. Mówiąc o skutkach trzeba jednak podkreślić, że bezpośrednio nigdy nie są one niebezpieczne dla aktualnego porządku

7 Wspominając o fałszywej sprawozdawczości jako przejawie działań oszukańczych należy zaznaczyć, że taka sprawozdawczość stanowi także niekiedy efekt bezpośredni działań pozornych w przyjętym tu znaczeniu. Dzieje się tak najczęściej wówczas, gdy osoby pracujące w jednostce przyjmującej sprawozdania same są zainteresowane tym, aby podawano w nich „upiększone" dane, podobnie jak i bezpośredni twórcy sprawozdań. W ten sposób pojawia się mechanizm, który powoduje zniekształcenie obrazu rzeczywistości, pogłębiające się przy jego przekazywaniu w górę. Działalność polegająca na tym „upiększaniu”, lub co najmniej silna tendencja w tym kierunku, występuje zawsze wtedy, gdy autorami sprawozdań są ci, których ocenia się na podstawie zawartych w nich danych, ponieważ dotyczą one ich działalności. Działania zmierzające do „upiększenia” obrazu rzeczywistości omawianego rodzaju stają się często działaniami oszukańczymi, gdy przekazy docierają do najwyższych szczebli lub do odbiorców na zewnątrz społecznego systemu. 
i systemu władzy, nie tylko nie podważają jawnie tego porządku, lecz przeciwnie, w pewnym sensie stanowią jego realizację, potwierdzając go.

Czy w związku z tym należy te skutki ocenić pozytywnie z punktu widzenia trwałości tego porządku? Chyba nie. Ich stabilizujące oddziaływanie jest bowiem tylko bezpośrednie, natychmiastowe, krótkotrwałe. Natomiast obniżenie na dłuższy czas morale obywatelskiego i pracowniczego trudno uznać za zjawisko pozytywne dla jakiegokolwiek społecznego systemu; są to dla niego zjawiska dysfunkcjonalne. Obfitość działań pozornych na pewno nie świadczy o zdrowiu i dobrych perspektywach rozwoju, przynajmniej w dotychczasowym kształcie. I chociaż pełna likwidacja działań pozornych nie wydaje się możliwa, przede wszystkim ze względu na nieuniknioną sztywność biurokratycznego systemu zarządzania i na koszty wprowadzania ciągłych modyfikacji przepisów, czasami także ze względu na rolę tych działań na zewnątrz danego społecznego systemu ${ }^{8}$, ograniczenie ich jest celowe i potrzebne. To ograniczenie należy uznać za celowe i potrzebne również wówczas, gdy działanie pozorne ocenia się ze stanowiska zakładającego trwałość i ciągłość systemu, co nie wyklucza przecież aprobaty dla jego zmiany.

Jeśli tak, to jaka droga czy drogi prowadzą w kierunku tego ograniczenia? Powinno być ich wiele, choćby ze względu na różnorodność źródeł wywołujących działania pozorne. W tych różnych drogach musi jednak wystąpić co najmniej jeden wspólny element. Jest nim zmniejszenie roli fikcji występujących w życiu społecznym, a więc jednocześnie - uznanie doniosłej roli w tym życiu wartości poznawczych. Ich pełna akceptacja i respektowanie związanych z tym wymagań sprawiają bowiem, że fikcje te, a więc i odpowiadające im działania pozorne, stają się niemożliwe.

[Pierwodruk: „Kultura i Społeczeństwo” 1977, nr 2]

\title{
APPARENT ACTIVITIES
}

\author{
Jan Lutyński
}

Summary

This is a reprint of an archival text by Jan Lutyński, an outstanding Polish sociologist, founder of the Łódź school of methodology, and co-founder of the Polish Sociological

\footnotetext{
${ }^{8}$ Pozorny charakter działań w przyjętym tutaj znaczeniu zawsze trzeba odnieść do jakiejś zbiorowości czy społecznego systemu. Działania, które są pozorne - w tym sensie - w ramach danego systemu, na zewnątrz mogą być działaniami oszukańczymi. Łączy się to z tym, że związany z omawianymi działaniami nacisk nie wywiera wpływu na zewnątrz, oraz z tym, że działania takie mogą przynieść określone korzyści, na przykład propagandowe, a nawet gospodarcze, ze względu na ich rolę zewnętrzną. Zewnętrzna funkcja tych działań lub ich wytworów może być nawet powodem, że podejmuje się je na wewnątrz. Sprawa rzetelnej informacji i odrzucania fikcji jest istotna również w aspekcie wewnętrznym.
} 
Association. The text is devoted to the imperfections of the political system in Poland in the 1970s-1980s and their negative social consequences in the form of "apparent activities." On the thirtieth anniversary of Professor Lutyński's death, the essay is worth rereading as it is still topical and has inspired many authors.

Key words / słowa kluczowe

Jan Lutyński, apparent activities / działania pozorne, Polish society / społeczeństwo polskie 